Vol. I No. 3 - December 2020

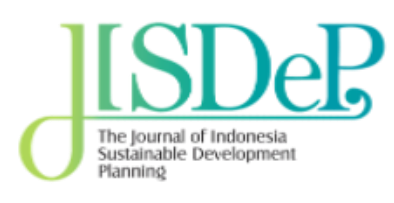

E-ISSN: $\underline{2722-0842}$ | P-ISSN: $\underline{2721-8309}$

Available online at

http://journal.pusbindiklatren.bappenas.go.id/

\title{
Commentary
}

\section{Expanding Middle Class in Indonesia}

\section{Devanto Shasta Pratomo ${ }^{1}$, Wildan Syafitri ${ }^{2}$, Clarissa Sekar Anindya ${ }^{3}$}

\author{
Department of Economics, Faculty of Economics and \\ Business, Universitas Brawijaya, Malang, Indonesia ${ }^{1,2}$ \\ Master Program in Economics, Faculty of Economics and \\ Business, Universitas Brawijaya, Malang, Indonesia ${ }^{3}$ \\ devanto@ub.ac.id; wilsyaf@gmail.com; \\ clarissanindya@gmail.com
}

\section{Introduction}

The Indonesian economy has been one of the promising economies, with an average annual economic growth of about $5 \%$ in the last decade. With income per capita US\$ 4050 as of 2019 , Indonesia is now moving to attain upper-middle-income country status. Indonesia escaped from the lower-middleincome trap that the country has faced since 1985 by improving its human capital through increased attention to education and reduction in poverty. Alongside a significant poverty reduction, the middle class or middle-income population has been significantly growing. According to the National SocioEconomic Survey (SUSENAS), the middle-class household grew from only $9 \%$ in 1993 to more than $20 \%$ in 2019. The middle class also works as an engine for growth, supporting nearly half of total national consumption. They are more likely of having better human capital, work as white-collar workers, and mostly living in urban areas. Due to the greater education and skills most of those in the middle class, have greater access to working in the formal sector jobs, and some are increasingly running productive business or entrepreneur which drives growth and creating jobs for others (Bank, 2019).

The size and characteristics of the middle class depend on how welfare is defined (D. S. Pratomo, 2020). Asian Development Bank, for example, characterized the middle class as comprising a population with daily per capita expenditure between \$2-20 per day (Afif, 2014). World Bank (Bank, 2019) in their report "Aspiring Indonesia - Expanding the Middle Class" defined the middle class as those who have less than 10 percent probability of going into poverty and vulnerability in the following year (specifically whose per capita household consumption is around 3.5-17 times the poverty line). According to their estimates, using both the National Socio-Economic Survey (SUSENAS) and Indonesian Family Life Survey (IFLS), the middle class in Indonesia was between $16 \%-20 \%$. This paper reviews some issues related to the potential growing number of middle-class jobs in Indonesia, related to education, youth unemployment, entrepreneurship, and digital competitiveness, and urbanization.

\section{ARTICLE INFO}

Received: Dec 21, 2020

Received in revised form: Dec 25, 2020

Accepted: Dec 25, 2020
JISDeP - The Journal of Indonesia Sustainable Development Planning Published by Centre for Planners'

Development, Education, and Training (Pusbindiklatren),

Ministry of National Development Planning/ National Development

Planning Agency (Bappenas), Republic of Indonesia
Address: Jalan Proklamasi 70 ,

Central Jakarta, Indonesia 10320

Phone: +62 $2131928280 / 3192828$

Fax: +62 2131928281

E-mail: pusbindiklatren@bappenas.go.id

Supported by Indonesian Development Planners

Association (PPPI) 


\section{Education and Youth Unemployment}

The expansion of higher-level education (secondary and tertiary levels) has had an enormous impact on the growth of the middle class in Indonesia. Almost $80 \%$ of the middle class now complete at least senior high school, and about one-third continue to attend some tertiary levels of education (Bank, 2019). Nearly all those who have tertiary education are categorized also as a middle (and upper) class. Hence, expanding the middle-class group will require more individuals finishing senior secondary school that can prepare them with the skills needed. For many of them, this was also an entrance ticket into the formal work sector or permanent sector employment. There was a significant expansion of formal sector employment, particularly in services during the last decade which has accounted for a large share of jobs for tertiary education graduates (D. Pratomo \& Manning, 2019).

Although universal education was increased from 9 years to 12 years, including senior secondary school, in 2016, the National Labor Force Survey (Sakernas) shows that the Indonesian workforce is still dominated by a lower level of education (D. S. Pratomo, 2020). In general, almost $60 \%$ of the total Indonesian labor force has an education equivalent to junior high school or below, while only $12 \%$ of the total labor force has a high tertiary education in 2019. However, the young age groups (20-29 years old) showed a significant positive trend of improving education rather than the total labor force. The World Bank (Bank, 2019) study also supported that the younger Indonesian cohort (up to 44 years old) mostly completes senior high school. However, from a regional comparison, there are very large differences in higher education completion levels between provinces. Some provinces in Indonesia, where the majority of the young labor force has at least a high school education, include DKI Jakarta, Yogyakarta, Riau Islands, North Sumatra, Bali, and Maluku (G. W. Jones \& Pratomo, 2016).

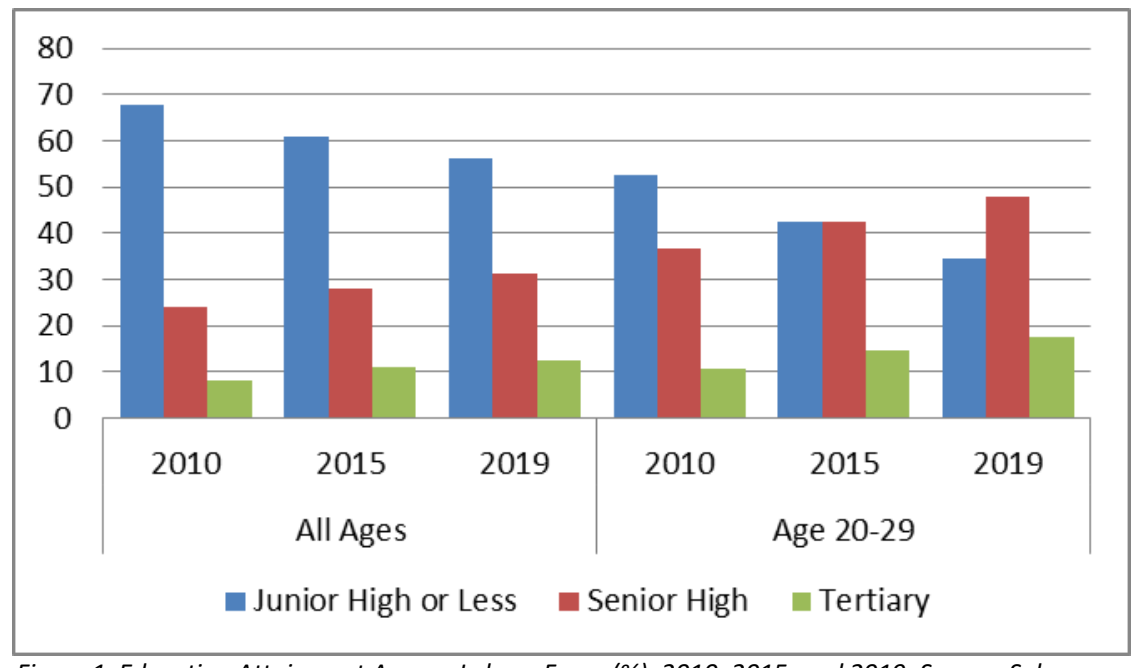

Figure 1. Education Attainment Among Labour Force (\%), 2010, 2015, and 2019. Source: Sakernas.

The significant changes in the national budget policy in 2002, which requires a minimum of $20 \%$ of the national budget for education, is one of the triggers for the success in increasing the education levels of the young labor force. For more than a decade, the expansion of vocational education has also been a serious concern. The government expands vocational education the Senior High School level (SMK) as one solution to the lack of technical middle-level employment. The number of SMK increased more than doubled (over 10,000), accounting for close to half of all Senior High School enrollments (Manning \& Pratomo, 2018). Moreover, the expansion of tertiary education has been even more rapid than at the secondary level. Indonesia is now also becoming one the largest and fastest-growing tertiary education sectors, with more than 5 million students enrolled in about 3600 institutions which are mainly administered by the Ministry of Education and Culture and the Ministry of Religious Affairs (Hill \& Wie, 2013).

Another challenge of higher education in Indonesia has been the high rates of unemployment among educated people compared with the total labor force. First, previous studies showed that there is a severe mismatch between education, particularly higher education, and the labor market. Allen (Allen, 2016) reported that only $40 \%$ of the employed workers in 2015 were well-matched with the educational requirement of their occupation, while more than $50 \%$ were under-qualified and about $8 \%$ were overqualified. Di Gropello (Gropello, 2013) also showed that about $80 \%$ of the manufacturing and services 
sectors have difficulties to find the right person for their vacancy. This suggests the need for the education sector to increase the relevance of secondary and tertiary education to the needs of the labor market in terms of expanding the potential people with middle-class jobs.

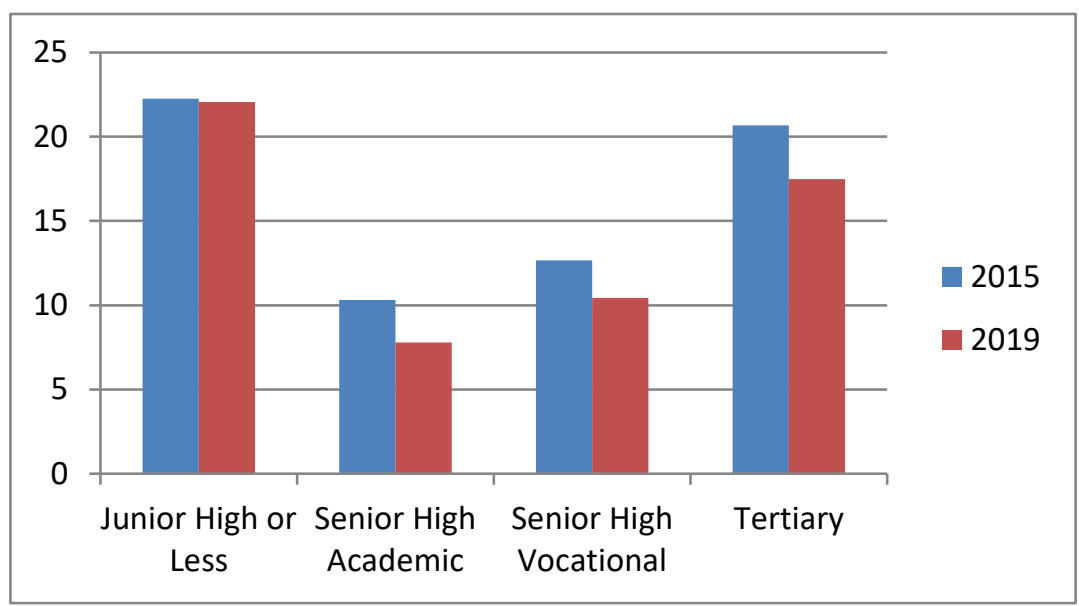

Figure 2. Youth Unemployment Rates by Education Attainment (\%), 2015 and 2019. Source: Sakernas.

Second, some educated young people prefer and choose to wait until they get the right job, mostly the formal sector work (so-called educated choosy youth) (Devanto Shasta Pratomo, 2017). Research from Allen (Allen, 2016) has shown that one-third of unemployed young people must wait for one year to enter the labor market, especially to enter the formal sector labor market. The mindset that the formal sector is always better, making most of them are waiting for opportunities to work in the formal sector, rather than enter the informal sector or starting up their own business. This is also considering that those unemployed with higher education are usually coming from families with a good economic background (luxury unemployment).

\section{Entrepreneurship and Digital Competitiveness}

Entrepreneurship is often considered to be a significant driver of growth because of creating a new product or innovation and also creates jobs for others (D. S. Pratomo, 2020). The entrepreneurial skill development system for the new entrants as well as for those who are no longer in the formal education system is needed. World Bank (Bank, 2019) noted that the middle class represents nearly half of all business owners with permanent employees. Based on Sakernas, although most of the middle class are wage employment $(80 \%)$, there is a significant growth of the middle-class entrepreneurs or self-employed (18\%), providing an alternative of limited wage employment jobs. Hence, some policy recommendations related to starting-up or ease of doing business are importantly needed.

Kusumawardhani (Kusumawardhani, Suryadarma, Tiberti, \& Indrio, 2019) found an interesting result about the skills needs by entrepreneurial success in Indonesia. They found that fluid intelligence (abilities that independent of education and experience) had sizeable and positive returns on business, while crystallized intelligence (problem-solving abilities influenced by their education, experience, or culture) had a positive and large effect only in sectors that required intense concentration or computers. The majority of household businesses in Indonesia tend to be labor-intensive that use low capital and simple technology, where high levels of crystallized intelligence would be of no significant advantage. Therefore, training programs might only be an effective tool to support the crystallized intelligence types in brain-intensive industries that require more innovation and higher technology. Developing industries with digital innovation orientation is one possible solution.

Compared to other countries, the digital competitiveness index of Indonesia is lagging behind some other countries in Asia. However, plenty of young and productive labor force during this demographic dividend period must be considered an opportunity, because the younger generation is the future generation that is more friendly to technological changes and digitalization. Digital technology has also been proven as a tool to expand middle-class jobs. Based on Sakernas 2019, about $78 \%$ of middle-class workers used digital technology in their work operation, mostly wage employment and self-employed. 
Interestingly, female middle-class workers have higher utilization of digital technology compared to males workers, suggesting potential areas for female workers to be developed.

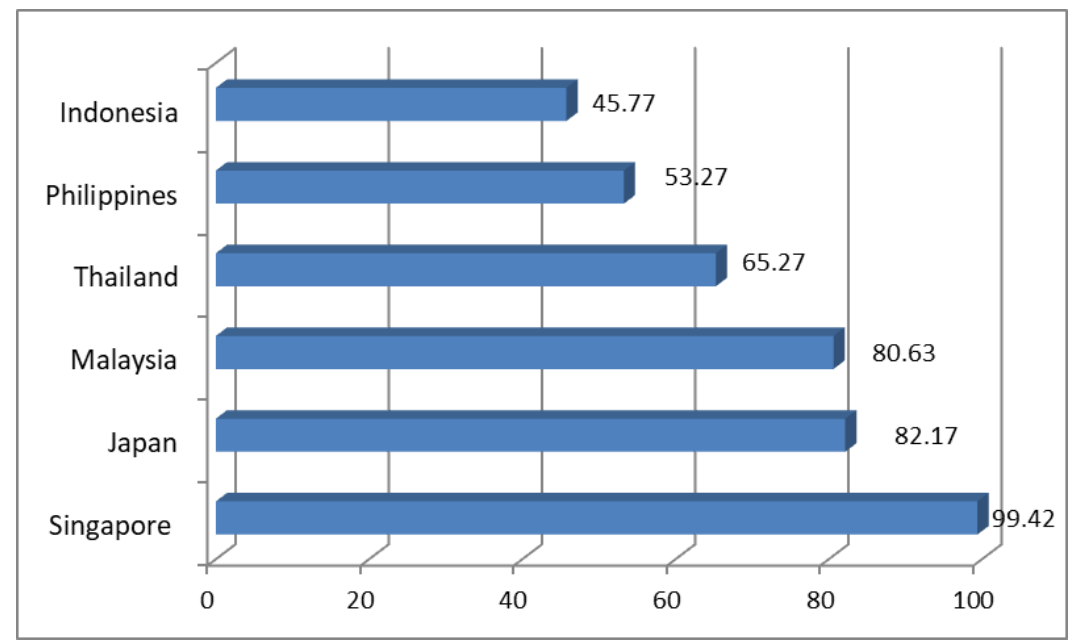

Figure 3. Digital Competitiveness Index in Some Asian Countries. Source: IMD World Competitiveness Centre.

Given the changing character of work, the competencies needed have also changed. Education or training policy must also be led towards providing a graduate that is friendly to digitalization. The involvement of the industry in the preparation of competency standards and educational curricula is mandatory. Completion of the educational curriculum, in addition to covering the composition of hardskills and soft-skills, must also be introduced to digital skills. Besides, such as job training, apprenticeship, vocational education, and re-training of active workers will also be important.

\section{Urbanization}

Indonesia has achieved a major milestone by increasing the percentage of the population living in urban areas by more than $50 \%$ in 2015 . The number is expected to keep increasing, making the majority of Indonesia's population never again live in rural areas (G. Jones \& Mulyana, 2015). Three possible elements contribute to the increasing proportion of the urban population (so-called urbanization) including natural population growth, reclassification of local status from rural to urban, and rural-urban migration. Unlike China and India, World Bank (Bank, 2018) reported that rather than migration, in Indonesia the process of urbanization is driven largely by the reclassification into the urban status of areas previously classified as rural (43\%). This is then followed by natural population growth (38\%). The significant numbers of area reclassifications in Indonesia are consistent with the decentralization policy in Indonesia that had been begun in 1999, growing many localities outside the cities. In contrast, most of the urbanization in China has been driven by rural-urban migration (56\%), while natural population growth had contributed significantly to urbanization in India (44\%).

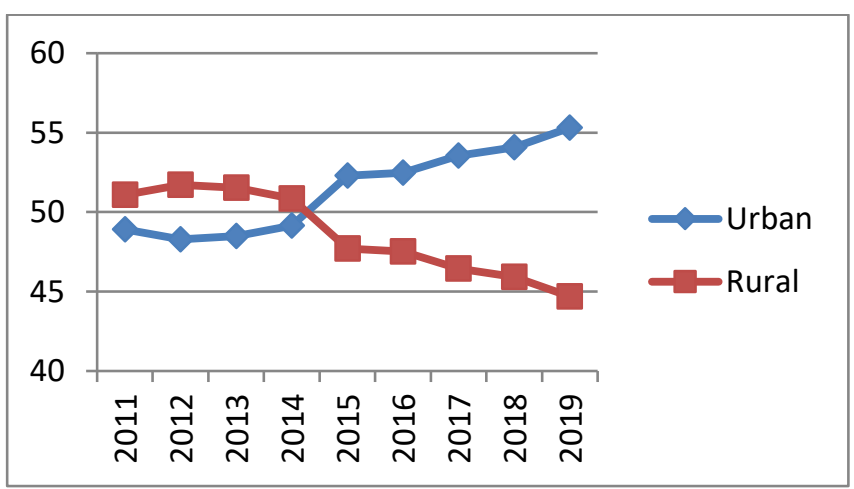

Figure 4. Labour Force in Urban and Rural Areas (\%), 2011-2019. Source: Sakernas. 
Urbanization has been usually associated with a structural shift in economic activity from the agriculture sector in rural areas to the manufacturing, trade, and service sectors (modern sectors) in urban areas. The types of activities that require highly skilled workers (with usually higher wages) are more likely to be located in urban areas (Tadjoeddin \& Mercer-Blackman, 2018). Manufacturing and services, of course, might be located in rural areas, but their main concentration is in urban areas (G. Jones \& Mulyana, 2015). However, if manufacturing grown in a rural area, that area is likely to become an urban area due to the potential reclassification of areas. Moreover, although most traditional farm activities remain a large part of rural economies, this does not necessarily mean that all the rural population is working in the agriculture sector. In 2019, for example, there are significant shares of workers living in rural areas working in trade (18\%), manufacturing (11\%), and services (10\%). A significant part of circular and commuting migrants from rural areas also works in urban areas, almost always in non-agricultural activities (Manning \& Pratomo, 2018).

Consistent with the existence of agglomeration economies, the growth of the urban population has a strong positive relationship with better economic opportunities (Bank, 2018). Urbanization has delivered on its potential, offering more stable, productive, higher-paying jobs in the modern sector and lower poverty rates. About the middle class, the World Bank (Bank, 2019) stated that $76 \%$ of the middle class live in urban areas. Consistently, SAKERNAS 2019 also supported that around $80 \%$ of middle-class workers are living in urban areas. Most of them worked in services (30\%), trade (19\%), and manufacturing (20\%). In contrast, only less than $10 \%$ of workers living in rural areas are categorized as middle-class workers. This implies that policies to support the expansion of middle-class jobs will need a strong urban dimension.

While urbanization is often framed as a driver of prosperity, it is not without its challenges. World Bank (Bank, 2019), for example, stated that the probability of a migrant entering the middle class has weakened, particularly in the city that suffers from urban congestion. Jakarta, in particular, is the most desired destination for the Indonesian middle class due to having the highest per capita income, which is far above any other Indonesian cities. As the center of governance, business, finance, trade, and services, Jakarta is now shouldering an overwhelming burden. Jakarta is also struggling under a huge environmental burden, whereas air quality in the city has plunged over the last few months. Housing is another issue, where construction has been unable to match the housing demand of the middle class in the last decade, creating a housing bubble where the growth of housing prices is much higher than workers' earnings. To address and relieve some of the burdens on Jakarta, in 2019 President Jokowi has announced that two regencies in East Kalimantan, Penajam Paser Utara, and Kutai Kartanegara districts are to be the site of the country's new capital city. Java is home to $60 \%$ of the country's population and more than half of its economic activity, while Kalimantan is almost four times bigger in size, but accounts for less than a tenth of the Gross Domestic Product, bringing some equal distribution of the economy across the region.

A growing urban population has also some important policy implications for the working-age population in rural areas, particularly in terms of maintaining the welfare of the people. The expansion of education for young people to have at least senior secondary education is one possible recommendation to seek employment outside traditional rural farms. Based on National labor force survey (SAKERNAS) 2019, the labor force in rural areas is dominated by a population with primary and junior secondary education. The expansion of agricultural mechanization is another potential policy that will increase the value-added of the rural agricultural sector. Also, there has to be an excellent perspective to be backed up on the upstream-downstream pattern in its supply chain to improve the productivity of the sector.

\section{Reference}

Afif, S. (2014). The Rising of Middle Class in Indonesia: Opportunity and Challenge.

Allen, E. R. (2016). Analysis of Trends and Challenges in the Indonesian Labor Market. In ADB Papers on Indonesia No. 16. Manila: Asian Development Bank, Manila.

Bank, W. (2018). Time to ACT: Realizing Indonesia's Urban Potential.

Bank, W. (2019). Aspiring Indonesia - Expanding the Middle Class.

Gropello, E. Di. (2013). Role of The Education and Training Sector in Addressing Skill Mismatch in Indonesia. In Education in Indonesia2. Singapore: Institute of Southeast Asian Studies, Singapore.

Hill, H., \& Wie, T. K. (2013). Indonesian Universities: Rapid Growth, Major Challenges. In D. S. \& G. Jones

(Ed.), Education in Indonesia. Singapore: Institute of Southeast Asian Studies, Singapore.

Jones, G., \& Mulyana, W. (2015). UNFPA Indonesia Monograph Series: No. 4: Urbanization in Indonesia. 
UNFPA Indonesia.

Jones, G. W., \& Pratomo, D. (2016). Education in Indonesia: trends, differentials, and implications for development. In Contemporary Demographic Transformations in China, India, and Indonesia (pp. 195-214). Springer, Cham.

Kusumawardhani, N., Suryadarma, D., Tiberti, L., \& Indrio, V. T. (2019). What Skills Lead to Entrepreneurial Success? Evidence from Non-Farm-Household Enterprises in Indonesia.

Manning, C., \& Pratomo, D. (2018). Labour Market Developments in the Jokowi Years. Journal of Southeast Asian Economies, 35(2).

Pratomo, D., \& Manning, C. (2019). The role of job transitions in supporting the growth of formal sector jobs.

Pratomo, D. S. (2020). Angkatan Kerja di Indonesia: Jalan Panjang Menuju Kelas Menengah, in Transformasi Ekonomi Indonesia Menuju Negara Maju dan Berdaya Saing. Jakarta: INDEF.

Pratomo, Devanto Shasta. (2017). Fenomena Pengangguran Terdidik di Indonesia. Sustainable Competitive Advantage (SCA), 7(1).

Tadjoeddin, M. Z., \& Mercer-Blackman, V. (2018). Urbanization \& Labor Productivity in Indonesia. In E. Ginting, C. Manning, \& K. Taniguchi (Eds.), Indonesia: Enhancing Productivity Through Quality Jobs. The Asian Development Bank. 